Supporting Information for

\title{
Elaboration of Proteins Containing Modified Arginine Residues
}

Ambar K. Choudhury, Serguei Y. Golovine, Larisa M. Dedkova, Andrei L. Laikhter and

Sidney M. Hecht* 


\section{EXPERIMENTAL PROCEDURES}

N-(4-Pentenoyl)-S-leucine pdCpA Ester.

$N$-(4-Pentenoyl)leucine. To a suspension of $605 \mathrm{mg}(4.6 \mathrm{mmol})$ of leucine in $12 \mathrm{~mL}$ of 1:1 water-dioxane was added $580 \mathrm{mg}(6.9 \mathrm{mmol})$ of $\mathrm{NaHCO}_{3}$. To this stirred solution was added $1.0 \mathrm{~g}(5.7 \mathrm{mmol})$ of the succinimidyl ester of pentenoic acid. The reaction mixture was stirred at $25^{\circ} \mathrm{C}$ for $4 \mathrm{~h}$, then acidified to $\mathrm{pH} 4$ by addition of $1 \mathrm{~N} \mathrm{NaHSO}_{4}$. The aqueous phase was extracted three times with $20-\mathrm{mL}$ portions of EtOAc. The combined organic phase was dried $\left(\mathrm{Na}_{2} \mathrm{SO}_{4}\right)$, filtered and concentrated under diminished pressure. The residue was crystallized from 20:1 ethyl acetate-methanol to afford $N$-(4-pentenoyl)leucine as colorless needles: yield $700 \mathrm{mg}(71 \%) ; \mathrm{mp} 122-124{ }^{\circ} \mathrm{C}$; silica gel TLC $R_{f} 0.36$ (ethyl acetate); ${ }^{1} \mathrm{H}$ NMR $\left(\mathrm{CD}_{3} \mathrm{OD}\right) \delta$ 0.85-0.91 (m, 6H), 1.53-1.66 (m, 3H), $2.27(\mathrm{~s}, 4 \mathrm{H}), 4.34-4.38(\mathrm{~m}, 1 \mathrm{H}), 4.83-5.02(\mathrm{~m}$,

$3 \mathrm{H})$ and 5.54-6.01 (m, 1H); ${ }^{13} \mathrm{C} \mathrm{NMR}\left(\mathrm{CD}_{3} \mathrm{OD}\right) \delta 21.7,23.4,26.0,30.8,36.1,41.6,51.8,115.8$,

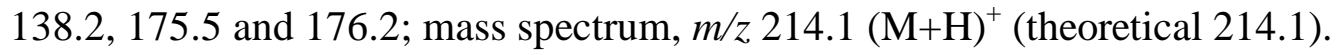

N-(4-Pentenoyl)leucine Cyanomethyl Ester. To $240 \mathrm{mg}(1.12 \mathrm{mmol})$ of $\mathrm{N}$-(4pentenoyl)leucine was added $10 \mathrm{~mL}$ of $\mathrm{CH}_{3} \mathrm{CN}$ and $775 \mu \mathrm{L}(4.5 \mathrm{mmol})$ of $N, N$ diisopropylethylamine followed by $165 \mu \mathrm{L}(2.25 \mathrm{mmol})$ of $\mathrm{ICH}_{2} \mathrm{CN}$. The reaction mixture was stirred at $25^{\circ} \mathrm{C}$ for $14 \mathrm{~h}$ and then treated with $15 \mathrm{~mL}$ of EtOAc. The organic phase was washed successively with $10-\mathrm{mL}$ portions of $1 \mathrm{~N} \mathrm{HCl}$ solution, saturated aq $\mathrm{NaHCO}_{3}$ and brine. The organic layer was dried $\left(\mathrm{Na}_{2} \mathrm{SO}_{4}\right)$, filtered and concentrated under diminished pressure. The residue was purified by flash chromatograpy on a silica gel column $(18 \times 3 \mathrm{~cm})$. Elution with 1:1 and then 2:1 ethyl acetate-hexane afforded $N$-(4-pentenoyl)leucine cyanomethyl ester as a yellow syrup: yield $200 \mathrm{mg}(70 \%)$; silica gel TLC $R_{f} 0.68$ (2:1 ethyl acetate-hexane); ${ }^{1} \mathrm{H}$ NMR 
$\left(\mathrm{CDCl}_{3}\right) \delta$ 0.94-0.95 (m, 6H), 1.54-1.71 (m, 3H), 2.33-2.40 (m, 4H), 4.64-4.85 (m, 3H), 5.00-

$5.10(\mathrm{~m}, 2 \mathrm{H})$ and 5.67-6.02 $(\mathrm{m}, 2 \mathrm{H})$; mass spectrum, $m / 2,253.1(\mathrm{M}+\mathrm{H})^{+}($theoretical 253.2).

$N$-(4-Pentenoyl)-S-leucine pdCpA Ester. A solution of the tris(tetrabutylammonium) salt of pdCpA (48) (4.0 mg, $2.9 \mu \mathrm{mol})$ dissolved in $50 \mu \mathrm{L}$ of freshly distilled DMF was added to a dry conical vial containing $25 \mathrm{mg}(99 \mu \mathrm{mol})$ of $N$-(4-pentenoyl)leucine cyanomethyl ester in 50 $\mu \mathrm{L}$ of anhydrous DMF. To this stirred solution was added $15 \mu \mathrm{L}$ of triethylamine. The reaction mixture was stirred at $25^{\circ} \mathrm{C}$ and monitored by $\mathrm{C}_{18}$ reversed phase HPLC. Eight- $\mu \mathrm{L}$ aliquots were removed periodically and diluted with $42 \mu \mathrm{L}$ of $1: 1 \mathrm{CH}_{3} \mathrm{CN}-50 \mathrm{mM} \mathrm{NH}_{4} \mathrm{OAc}, \mathrm{pH} 4.5 ; 20$ $\mu \mathrm{L}$ of each diluted aliquot was analyzed on a $3 \mu \mathrm{m} \mathrm{C}_{18}$ reversed phase HPLC column ( $250 \times 10$ $\mathrm{mm})$. The column was washed with $1 \% \rightarrow 63 \% \mathrm{CH}_{3} \mathrm{CN}-50 \mathrm{mM} \mathrm{NH} \mathrm{H}_{4} \mathrm{OAc}, \mathrm{pH} 4.5$, over a period of $45 \mathrm{~min}$ at a flow rate of $3.5 \mathrm{~mL} / \mathrm{min}$ (detection at $260 \mathrm{~nm}$; the desired 2'- and 3'- $O$ aminoacylated products eluted at $18.3 \mathrm{~min}$ and $18.8 \mathrm{~min}$ ). After $25 \mathrm{~h}$, the remaining reaction

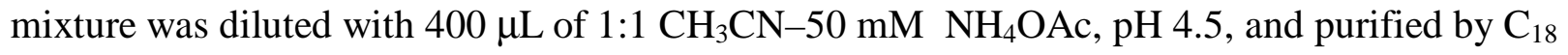
reversed phase HPLC on a semi-preparative column $(250 \times 10 \mathrm{~mm})$ using the same gradient as described above. $N$-(4-Pentenoyl)-S-leucine pdCpA ester was recovered from the appropriate fractions as a colorless solid following lyophilization: yield ( $2 \mathrm{mg}, 83 \%)$; mass spectrum, $\mathrm{m} / \mathrm{z}$ $832.2(\mathrm{M}+\mathrm{H})^{+}$(theoretical 832.2).

N-(4-Pentenoyl)-S-arginine pdCpA Ester (1-pdCpA). $\mathrm{N}$-(4-Pentenoyl)-S-arginine. Arginine (500 mg, $2.87 \mathrm{mmol}$ ) was dissolved in $15 \mathrm{~mL}$ of 1:1 water-dioxane and treated with $361 \mathrm{mg}(4.3 \mathrm{mmol})$ of $\mathrm{NaHCO}_{3}$. To this stirred solution was added $622 \mathrm{mg}$ ( $3.15 \mathrm{mmol})$ of the succinimidyl ester of 4-pentenoic acid (46). The reaction mixture was stirred at $25^{\circ} \mathrm{C}$ for $16 \mathrm{~h}$ and then acidified to $\mathrm{pH} 4$ by the addition of $1 \mathrm{~N} \mathrm{NaHSO}_{4}$. The aqueous phase was extracted with $20 \mathrm{~mL}$ of ethyl acetate and the organic layer was 
discarded. The aqueous phase was concentrated under diminished pressure. The residue was suspended in $20 \mathrm{~mL}$ of methanol and the insoluble solid was filtered. The solid was washed twice with $10-\mathrm{mL}$ portions of methanol. The combined methanol extract was concentrated under diminished pressure. The residue was purified by flash chromatography on a silica gel column (30 x $3 \mathrm{~cm})$. Elution with 1:1, 2:1, 3:1 and then 4:1 methanol-ethyl acetate afforded $N$-(4pentenoyl)-S-arginine as a colorless foam: yield $700 \mathrm{mg}$ (95\%); silica gel TLC $R_{f} 0.3$ (4:1 methanol-ethyl acetate); ${ }^{1} \mathrm{H}$ NMR $\left(\mathrm{CD}_{3} \mathrm{OD}\right) \delta$ 1.51-1.84 (m, 4H), 2.28-2.30 (m, 4H), 3.09-3.25 $(\mathrm{m}, 2 \mathrm{H}), 4.18-4.22(\mathrm{~m}, 1 \mathrm{H}), 4.90-5.03(\mathrm{~m}, 2 \mathrm{H})$ and 5.74-5.83 $(\mathrm{m}, 1 \mathrm{H}) ;{ }^{13} \mathrm{C} \mathrm{NMR}\left(\mathrm{CD}_{3} \mathrm{OD}\right) \delta$ 25.8, 30.4, 30.5, 36.0, 41.5, 54.8, 115.3, 137.9, 158.1, 174.3 and 178.4; mass spectrum (CI, methane) $m / z 257.2(\mathrm{M}+\mathrm{H})^{+}$; mass spectrum (FAB), $m / z 257.1619\left(\mathrm{C}_{11} \mathrm{H}_{21} \mathrm{~N}_{4} \mathrm{O}_{3}\right.$ requires 257.1614).

$N$-(4-Pentenoyl)-S-arginine Cyanomethyl Ester. N-(4-Pentenoyl)-S-arginine (270 mg, $1.05 \mathrm{mmol}$ ) was dissolved in $6 \mathrm{~mL}$ of DMF and heated at $45-50{ }^{\circ} \mathrm{C}$. To this stirred solution was added $724 \mu \mathrm{L}$ (4.2 mmol) of $N, N$-diisopropylethylamine followed by $135 \mu \mathrm{L}$ ( $2.1 \mathrm{mmol})$ of $\mathrm{ClCH}_{2} \mathrm{CN}$. The reaction mixture was stirred at $45-50{ }^{\circ} \mathrm{C}$ for $48 \mathrm{~h}$ and then concentrated under diminished pressure. The residue was purified by silica gel flash chromatography $(20 \times 3 \mathrm{~cm}$ column). Elution with 1:1 and then 2:1 ethyl acetate-methanol afforded $N$-(4-pentenoyl)-Sarginine cyanomethyl ester as a syrup: yield $100 \mathrm{mg}$ (32\%); silica gel TLC $R_{f} 0.54$ (1:1 ethyl acetate-methanol); ${ }^{1} \mathrm{H}$ NMR $\left(\mathrm{CD}_{3} \mathrm{OD}\right) \delta$ 1.55-1.90 (m, 4H), 2.29-2.31 (m, 4H), 3.12-3.24 (m, 2H), 4.35-4.45 (m, 1H), $4.79(\mathrm{~s}, 1 \mathrm{H}), 4.86(\mathrm{~d}, 1 \mathrm{H}, J=1.5 \mathrm{~Hz}), 4.91-5.04(\mathrm{~m}, 2 \mathrm{H})$ and 5.74-5.83 (m, 1H); mass spectrum (chemical ionization, methane), $\mathrm{m} / \mathrm{z} 296.2(\mathrm{M}+\mathrm{H})^{+}$; mass spectrum (FAB) $m / z 296.1727\left(\mathrm{C}_{13} \mathrm{H}_{22} \mathrm{~N}_{5} \mathrm{O}_{3}\right.$ requires 296.1723). 
$N$-(4-Pentenoyl)-S-arginine pdCpA Ester (1-pdCpA). A solution of the tris(tetrabutylammonium) salt of pdCpA (48) $(4.1 \mathrm{mg}, 3 \mu \mathrm{mol})$ dissolved in $50 \mu \mathrm{L}$ of anhydrous DMF was added to a dry conical vial containing $18 \mathrm{mg}(61 \mu \mathrm{mol})$ of $N$-(4-pentenoyl)-S-arginine cyanomethyl ester in $100 \mu \mathrm{L}$ of anhydrous DMF. To this stirred solution was added $10 \mu \mathrm{L}$ of triethylamine. The reaction mixture was stirred at $25^{\circ} \mathrm{C}$ and monitored by HPLC. Eight- $\mu \mathrm{L}$ aliquots were removed and diluted with $42 \mu \mathrm{L}$ of $1: 1 \mathrm{CH}_{3} \mathrm{CN}-50 \mathrm{mM} \mathrm{NH}_{4} \mathrm{OAc}, \mathrm{pH} 4.5 ; 20 \mu \mathrm{L}$ of each diluted aliquot was analyzed on a $3 \mu \mathrm{m} \mathrm{C}_{18}$ reversed phase HPLC column $(250 \times 10$ $\mathrm{mm})$. The column was washed with $1 \% \rightarrow 63 \% \mathrm{CH}_{3} \mathrm{CN}-50 \mathrm{mM} \mathrm{NH}_{4} \mathrm{OAc}, \mathrm{pH} 4.5$, over a period of $45 \mathrm{~min}$ at a flow rate of $3.5 \mathrm{~mL} / \mathrm{min}$ (detection at $260 \mathrm{~nm}$; the desired product eluted at 14.66 $\min )$. After $48 \mathrm{~h}$, the remaining reaction mixture was diluted with $400 \mu \mathrm{L}$ of $1: 1 \mathrm{CH}_{3} \mathrm{CN}-50$ $\mathrm{mM} \mathrm{NH} \mathrm{N}_{4} \mathrm{OAc}, \mathrm{pH} 4.5$, and purified by $\mathrm{C}_{18}$ reversed phase HPLC on a semi-preparative column (250 x $10 \mathrm{~mm}$ ) using the same gradient as described above. $N$-(4-Pentenoyl)-S-arginine pdCpA 3 ster (1-pdCpA) was recovered from the appropriate fractions as a colorless solid following lyophilization: yield $0.5 \mathrm{mg}(19 \%)$; mass spectrum (ESI), $\mathrm{m} / z, 875.2(\mathrm{M}+\mathrm{H})^{+}$; mass spectrum (FAB), $m / z \quad 875.2551\left(\mathrm{C}_{30} \mathrm{H}_{45} \mathrm{~N}_{12} \mathrm{O}_{15} \mathrm{P}_{2}\right.$ requires 875.2603).

$N$-(4-Pentenoyl)-N"-methyl-S-arginine pdCpA Ester (2-pdCpA). $N$-(4-Pentenoyl)-N"-methyl-S-arginine. $N^{\gamma}$-Methyl-S-arginine (300 mg, $\left.1.21 \mathrm{mmol}\right)$ was dissolved in $10 \mathrm{~mL}$ of 1:1 water-dioxane and treated with $203 \mathrm{mg}$ (2.4 mmol) of $\mathrm{NaHCO}_{3}$. To this stirred solution was added $262 \mathrm{mg}(1.33 \mathrm{mmol})$ of the succinindyl ester of 4-pentenoic acid (46). The reaction mixture was stirred at $25^{\circ} \mathrm{C}$ for $5 \mathrm{~h}$ and then acidified to $\mathrm{pH} 4$ by the addition of $1 \mathrm{~N} \mathrm{NaHSO}_{4}$. The aqueous phase was extracted with $15 \mathrm{~mL}$ of ethyl acetate and the organic layer was discarded. The aqueous phase was concentrated under diminished pressure. The residue was suspended in $20 \mathrm{~mL}$ of methanol and the insoluble solid was filtered. The solid was 
washed twice with 10 -mL portions of methanol. The combined methanol extract was concentrated under diminished pressure. The residue was purified by flash chromatography on a silica gel column $(28 \times 3 \mathrm{~cm})$. Elution with ethyl acetate, followed by 4:1, 2:1 and 1:1 ethyl acetate-methanol and finally with methanol, afforded $N$-(4-pentenoyl)- $N^{\gamma}$-methyl-S-arginine as colorless foam: yield $305 \mathrm{mg}$ (93\%); silica gel TLC $R_{f} 0.5$ (methanol); ${ }^{1} \mathrm{H}$ NMR $\left(\mathrm{CD}_{3} \mathrm{OD}\right) \delta$ 1.50-1.82 (m, 4H), 2.26-2.31 (m, 4H), $2.77(\mathrm{~s}, 3 \mathrm{H}), 3.11-3.24(\mathrm{~m}, 2 \mathrm{H}), 4.19-4.23(\mathrm{~m}, 1 \mathrm{H}), 4.89-$ $5.04(\mathrm{~m}, 2 \mathrm{H})$ and 5.74-5.83 (m, 1H); mass spectrum (ESI), $\mathrm{m} / z 271.3(\mathrm{M}+\mathrm{H})^{+}$; mass spectrum (FAB), $m / z 271.1778\left(\mathrm{C}_{12} \mathrm{H}_{23} \mathrm{~N}_{4} \mathrm{O}_{3}\right.$ requires 271.1770).

$N$-(4-Pentenoyl)-N"-methyl-S-arginine Cyanomethyl Ester. $N$-(4-Pentenoyl)- $N^{\prime}$-methyl$S$-arginine $(85 \mathrm{mg}, 0.31 \mathrm{mmol})$ was dissolved in $3 \mathrm{~mL}$ of DMF and heated at $45-50{ }^{\circ} \mathrm{C}$. To this stirred solution was added $162 \mu \mathrm{L}(0.94 \mathrm{mmol})$ of $N, N$-diisopropylethylamine followed by $35 \mu \mathrm{L}$ $(0.47 \mathrm{mmol})$ of $\mathrm{ICH}_{2} \mathrm{CN}$. The reaction mixture was stirred at $45-50{ }^{\circ} \mathrm{C}$ for $24 \mathrm{~h}$ and then concentrated under diminished pressure. The residue was purified by flash chromatography on a silica gel column $(30 \times 2 \mathrm{~cm})$. Elution with 8:1, 4:1, 2:1 and 1:1 ethyl acetate-methanol afforded $N$-(4-pentenoyl)- $N^{\gamma}$-methyl-S-arginine cyanomethyl ester as a syrup: yield $60 \mathrm{mg}(62 \%)$; silica gel TLC $R_{f} 0.23$ (4:1 ethyl acetate-methanol); ${ }^{1} \mathrm{H}$ NMR $\left(\mathrm{CD}_{3} \mathrm{OD}\right) \delta 1.56-1.93(\mathrm{~m}, 4 \mathrm{H}), 2.26-2.34$ (m, 4H), $2.79(\mathrm{~s}, 3 \mathrm{H}), 3.14-3.25(\mathrm{~m}, 2 \mathrm{H}), 4.40-4.47(\mathrm{~m}, 1 \mathrm{H}), 4.82(\mathrm{~s}, 2 \mathrm{H}), 4.98-5.07(\mathrm{~m}, 2 \mathrm{H})$ and 5.74-5.83 (m, 1H); mass spectrum (ESI), $\mathrm{m} / z 310.4(\mathrm{M}+\mathrm{H})^{+}$; mass spectrum (FAB), $\mathrm{m} / \mathrm{z}$ 310.1884 $\left(\mathrm{C}_{14} \mathrm{H}_{24} \mathrm{~N}_{5} \mathrm{O}_{3}\right.$ requires 310.1879). $N$-(4-Pentenoyl)-N"-methyl-S-arginine pdCpA Ester (2-pdCpA). A solution of the tris(tetrabutylammonium) salt of pdCpA (48) $(4.5 \mathrm{mg}, 3.3 \mu \mathrm{mol})$ dissolved in $50 \mu \mathrm{L}$ of anhydrous DMF was added to a dry conical vial containing $15 \mathrm{mg}(48.5 \mu \mathrm{mol})$ of $\mathrm{N}$-(4pentenoyl)- $N^{\gamma}$-methyl-S-arginine cyanomethyl ester in $50 \mu \mathrm{L}$ of anhydrous DMF. To this stirred 
solution was added $10 \mu \mathrm{L}$ of triethylamine. The reaction mixture was stirred at $25^{\circ} \mathrm{C}$ and monitored by HPLC. Four- $\mu \mathrm{L}$ aliquots were removed and diluted with $23 \mu \mathrm{L}$ of $1: 1 \mathrm{CH}_{3} \mathrm{CN}-50$ mM NH $\mathrm{m}_{4} \mathrm{OAc}, \mathrm{pH} 4.5$, and $23 \mu \mathrm{L}$ of water; $30 \mu \mathrm{L}$ of that diluted aliquot was analyzed on a $3 \mu \mathrm{m}$ $\mathrm{C}_{18}$ reversed phase HPLC column $(250 \times 10 \mathrm{~mm})$. The column was washed with $1 \% \rightarrow 63 \%$ $\mathrm{CH}_{3} \mathrm{CN}-50 \mathrm{mM} \mathrm{NH} \mathrm{m}_{4} \mathrm{OAc}, \mathrm{pH} 4.5$, over a period of $45 \mathrm{~min}$ at a flow rate of $3.5 \mathrm{~mL} / \mathrm{min}$ (detection at $260 \mathrm{~nm}$; the (2' and 3' isomers of the) desired product eluted at $13.1 \mathrm{~min}$ and 13.5 min). After $18 \mathrm{~h}$, the remaining reaction mixture was diluted with $200 \mu \mathrm{L}$ of $1: 1 \mathrm{CH}_{3} \mathrm{CN}-50 \mathrm{mM}$ $\mathrm{NH}_{4} \mathrm{OAc}, \mathrm{pH} 4.5$, and $200 \mu \mathrm{L}$ of water and purified by $\mathrm{C}_{18}$ reversed phase HPLC on a semipreparative column $(250 \times 10 \mathrm{~mm})$ using the same gradient as described above. $\mathrm{N}$-(4Pentenoyl)- $N^{\gamma}$-methyl- $S$-arginine pdCpA ester (2-pdCpA). was recovered from the appropriate fractions as a colorless solid following lyophilization: yield $0.8 \mathrm{mg}(27 \%)$; mass spectrum (ESI), $m / z \quad 889.4(\mathrm{M}+\mathrm{H})^{+}$; mass spectrum (FAB), $m / z 889.2778\left(\mathrm{C}_{31} \mathrm{H}_{47} \mathrm{~N}_{12} \mathrm{O}_{15} \mathrm{P}_{2}\right.$ requires 889.2759). $N$-(4-Pentenoyl)-N'-nitro-S-arginine pdCpA Ester (3-pdCpA). $N$-(4-Pentenoyl)-N" $N^{\prime}$-nitro-S-arginine. $N^{\gamma}$-Nitro-S-arginine (500 mg, $\left.2.28 \mathrm{mmol}\right)$ was dissolved in $10 \mathrm{~mL}$ of 1:1 water-dioxane and treated with $383 \mathrm{mg}(4.56 \mathrm{mmol})$ of $\mathrm{NaHCO}_{3}$. To this stirred solution was added $450 \mathrm{mg}(2.28 \mathrm{mmol})$ of the succinimidyl ester of 4-pentenoic acid (46). The reaction mixture was stirred at $25^{\circ} \mathrm{C}$ for $6 \mathrm{~h}$ and then acidified to $\mathrm{pH} 4$ by the addition of $1 \mathrm{~N} \mathrm{NaHSO}_{4}$. The aqueous phase was extracted with $15 \mathrm{~mL}$ of ethyl acetate and the organic layer was discarded. The aqueous phase was concentrated under diminished pressure. The residue was suspended in $20 \mathrm{~mL}$ of methanol and the insoluble solid was filtered. The solid was washed twice with $10-\mathrm{mL}$ portions of methanol. The combined methanol extract was concentrated under diminished pressure. The residue was purified by flash chromatography on a silica gel column $(20 \times 3 \mathrm{~cm})$. Elution with 10:1, 8:1, 4:1, 2:1 and then 1:1 ethyl acetate- 
methanol afforded $N$-(4-pentenoyl)- $N^{\gamma}$-nitro-S-arginine as a colorless foam: yield $450 \mathrm{mg}$ (66\%); silica gel TLC $R_{f} 0.46$ (1:1 methanol-ethyl acetate); ${ }^{1} \mathrm{H}$ NMR $\left(\mathrm{CD}_{3} \mathrm{OD}\right) \delta 1.59-1.86(\mathrm{~m}, 4 \mathrm{H})$, 2.26-2.35 (m, 4H), 3.18-3.24 (m, 2H), 4.20-4.24 (m, 1H), 4.89-5.03 (m, 2H) and 5.74-5.83 (m, 1H); mass spectrum (ESI), $m / z, 302.2(\mathrm{M}+\mathrm{H})^{+}$; mass spectrum (FAB), $m / z, 302.1465$ $\left(\mathrm{C}_{11} \mathrm{H}_{20} \mathrm{~N}_{5} \mathrm{O}_{5}\right.$ requires 302.1465).

$N$-(4-Pentenoyl)-N" $N^{\prime \prime}$-nitro-S-arginine Cyanomethyl Ester (19). $N$-(4-Pentenoyl)- $N^{\prime}$-nitro$S$-arginine $(75 \mathrm{mg}, 0.25 \mathrm{mmol}$ ) was dissolved in $3 \mathrm{~mL}$ of anhydrous DMF and heated at 45-50 ${ }^{\circ} \mathrm{C}$. To this stirred solution was added $130 \mu \mathrm{L}(0.75 \mathrm{mmol})$ of $N, N$-diisopropylethylamine followed by $27 \mu \mathrm{L}(0.37 \mathrm{mmol})$ of $\mathrm{ICH}_{2} \mathrm{CN}$. The reaction mixture was stirred at $45-50{ }^{\circ} \mathrm{C}$ for 24 $\mathrm{h}$ and then concentrated under diminished pressure. The residue was purified by flash chromatography on a silica gel column $(30 \times 2 \mathrm{~cm})$. Elution with ethyl acetate followed by $8: 1$ and 4:1 ethyl acetate-methanol afforded $N$-(4-pentenoyl)- $N^{\gamma}$-nitro-S-arginine cyanomethyl ester as a yellow solid: yield $65 \mathrm{mg}$ (76\%); silica gel TLC $R_{f} 0.75$ (4:1 ethyl acetate-methanol); ${ }^{1} \mathrm{H}$ NMR $\left(\mathrm{CD}_{3} \mathrm{OD}\right) \delta 1.61-1.91(\mathrm{~m}, 4 \mathrm{H}), 2.25-2.32(\mathrm{~m}, 4 \mathrm{H}), 3.17-3.28(\mathrm{~m}, 2 \mathrm{H}), 4.37-4.45(\mathrm{~m}, 1 \mathrm{H})$, $4.85(\mathrm{~s}, 1 \mathrm{H}), 4.91(\mathrm{~s}, 1 \mathrm{H}), 4.91-5.03(\mathrm{~m}, 2 \mathrm{H})$ and $5.73-5.83(\mathrm{~m}, 1 \mathrm{H})$; mass spectrum $(\mathrm{ESI}), \mathrm{m} / \mathrm{z}$ $341.2(\mathrm{M}+\mathrm{H})^{+}$; mass spectrum (FAB) $\mathrm{m} / 2341.1583\left(\mathrm{C}_{13} \mathrm{H}_{21} \mathrm{~N}_{6} \mathrm{O}_{5}\right.$ requires 341.1573). $N$-(4-Pentenoyl)-N"-nitro-S-arginine pdCpA Ester (3-pdCpA). A solution of the tris(tetrabutylammonium) salt of pdCpA (48) $(4.5 \mathrm{mg}, 3.3 \mu \mathrm{mol})$ dissolved in $50 \mu \mathrm{L}$ of anhydrous DMF was added to a dry conical vial containing $20 \mathrm{mg}$ (58 $\mu \mathrm{mol})$ of $N$-(4-pentenoyl)$N^{\gamma}$-nitro-S-arginine cyanomethyl ester in $50 \mu \mathrm{L}$ of anhydrous DMF. To this stirred solution was added $10 \mu \mathrm{L}$ of triethylamine. The reaction mixture was stirred at $25^{\circ} \mathrm{C}$ and monitored by HPLC. Four- $\mu \mathrm{L}$ aliquots were removed and diluted with $46 \mu \mathrm{L}$ of $2: 1 \mathrm{CH}_{3} \mathrm{CN}-50 \mathrm{mM}$ $\mathrm{NH}_{4} \mathrm{OAc}, \mathrm{pH} 4.5 ; 30 \mu \mathrm{L}$ of that diluted aliquot was analyzed on a $3 \mu \mathrm{m} \mathrm{C}_{18}$ reversed phase 
HPLC column $(250 \times 10 \mathrm{~mm})$. The column was washed with $1 \% \rightarrow 63 \% \mathrm{CH}_{3} \mathrm{CN}-50 \mathrm{mM}$ $\mathrm{NH}_{4} \mathrm{OAc}, \mathrm{pH} 4.5$, over a period of $45 \mathrm{~min}$ at a flow rate of $3.5 \mathrm{~mL} / \mathrm{min}$ (detection at $260 \mathrm{~nm}$; the 2' and 3' isomers of the desired product eluted at $13.75 \mathrm{~min}$ and $14.89 \mathrm{~min}$ ). After $18 \mathrm{~h}$, the remaining reaction mixture was diluted with $300 \mu \mathrm{L}$ of 2:1 $\mathrm{CH}_{3} \mathrm{CN}-50 \mathrm{mM} \mathrm{NH}_{4} \mathrm{OAc}, \mathrm{pH} 4.5$, and purified by $\mathrm{C}_{18}$ reversed phase HPLC on a semi-preparative column ( $\left.250 \times 10 \mathrm{~mm}\right)$ using the same gradient as described above. $\quad N$-(4-Pentenoyl)- $N^{\gamma}$-nitro-S-arginine pdCpA ester (3pdCpA). was recovered from the appropriate fractions as a colorless solid following lyophilization: yield $2.2 \mathrm{mg}(72 \%)$; mass spectrum (ESI), $\mathrm{m} / z \quad 920.3(\mathrm{M}+\mathrm{H})^{+}$; mass spectrum (FAB), $m / z \quad 920.2465\left(\mathrm{C}_{30} \mathrm{H}_{44} \mathrm{~N}_{13} \mathrm{O}_{17} \mathrm{P}_{2}\right.$ requires 920.2454).

N-(4-Pentenoyl)-(S)-citrulline pdCpA Ester (4-pdCpA).

$N$-(4-Pentenoyl)-(S)-citrulline. (R,S)-Citrulline $(500 \mathrm{mg}, 2.85 \mathrm{mmol})$ was dissolved in 15 $\mathrm{mL}$ of $(1: 1)$ water-dioxane and treated with $360 \mathrm{mg}(4.28 \mathrm{mmol})$ of $\mathrm{NaHCO}_{3}$. To this stirred solution was added $620 \mathrm{mg}(3.14 \mathrm{mmol})$ of the succinimidyl ester of pentenoic acid (46). The reaction mixture was stirred at $25{ }^{\circ} \mathrm{C}$ for $14 \mathrm{~h}$ and then acidified to $\mathrm{pH} 4$ by the addition of $1 \mathrm{~N}$ $\mathrm{NaHSO}_{4}$. The aqueous solution was concentrated under diminished pressure. The residue was suspended in $25 \mathrm{~mL}$ of methanol and the insoluble solid was filtered. The solid was washed two times with $15-\mathrm{mL}$ portions of methanol. The combined methanol extract was concentrated under diminished pressure. The residue was purified by flash chromatography on a silica gel column (20 $3 \mathrm{~cm})$. Elution with 4:1, 2:1, 1:1, 1:2 and then 1:4 ethyl acetate-methanol afforded $N$-(4pentenoyl)-(S)-citrulline as a colorless foam: yield $600 \mathrm{mg}$ (82\%); silica gel TLC $R_{f} 0.27$ (1:1 ethyl acetate-methanol); ${ }^{1} \mathrm{H}$ NMR $\left(\mathrm{CD}_{3} \mathrm{OD}\right) \delta$ 1.44-1.81 (m, 4H), 2.25-2.30 (m, 4H), 2.99-3.12 (m, 2H), 4.23-4.27 (m, 1H), 4.89-5.03 (m, 2H) and 5.74-5.79 (m, 1H); ${ }^{13} \mathrm{C} \mathrm{NMR}\left(\mathrm{CD}_{3} \mathrm{OD}\right) \delta$ 
27.1, 30.3, 30.4, 35.9, 39.8, 54.9, 115.3, 137.9, 161.7, 174.4 and 179.0; mass spectrum (chemical ionization, methane), $m / z 258.0(\mathrm{M}+\mathrm{H})^{+}$(theoretical 258.1).

N-(4-Pentenoyl)-(S)-citrulline Cyanomethyl Ester. $N$-(4-Pentenoyl)-(S)-citrulline (240 $\mathrm{mg}, 0.93 \mathrm{mmol}$ ) was dissolved in $10 \mathrm{~mL}$ of $\mathrm{DMF}$ and heated at $45-50{ }^{\circ} \mathrm{C}$. To this stirred solution was added $650 \mu \mathrm{L}(4.65 \mathrm{mmol})$ of triethylamine followed by $118 \mu \mathrm{L}(1.86 \mathrm{mmol})$ of $\mathrm{ClCH}_{2} \mathrm{CN}$. The reaction mixture was stirred at $45-50{ }^{\circ} \mathrm{C}$ for $24 \mathrm{~h}$ and then concentrated under diminished pressure. The residue was purified by flash chromatography on a silica gel column $(35 \mathrm{x} 3 \mathrm{~cm})$. Elution with 4:1 and then 2:1 ethyl acetate-methanol afforded $N$-(4-pentenoyl)-(S)-citrulline cyanomethyl ester as a syrup: yield $90 \mathrm{mg}$ (33\%); silica gel TLC $R_{f} 0.83$ (1:1 ethyl acetatemethanol); ${ }^{1} \mathrm{H}$ NMR $\left(\mathrm{CD}_{3} \mathrm{OD}\right) \delta$ 1.44-1.63 (m, 2H), 1.66-1.85 (m, 2H), 2.26-2.29 (m, 4H), 3.04$3.09(\mathrm{~m}, 2 \mathrm{H}), 4.35-4.40(\mathrm{~m}, 1 \mathrm{H}), 4.84(\mathrm{~s}, 2 \mathrm{H}), 4.91-5.04(\mathrm{~m}, 2 \mathrm{H})$ and 5.74-5.79 $(\mathrm{m}, 1 \mathrm{H})$; mass spectrum (chemical ionization, methane), $\mathrm{m} / z, 297.0(\mathrm{M}+\mathrm{H})^{+} ;$mass spectrum $(\mathrm{FAB}), \mathrm{m} / z$ $297.1564\left(\mathrm{C}_{13} \mathrm{H}_{21} \mathrm{~N}_{4} \mathrm{O}_{4}\right.$ requires 297.1563).

N-(4-Pentenoyl)-(S)-citrulline pdCpA Ester (4-pdCpA). A solution of the tris(tetrabutylammonium) salt of pdCpA (48) $(3.5 \mathrm{mg}, 2.57 \mu \mathrm{mol})$ dissolved in $50 \mu \mathrm{L}$ of anhydrous DMF was added to a dry conical vial containing $30 \mathrm{mg}(101 \mu \mathrm{mol})$ of the cyanomethyl ester in $50 \mu \mathrm{L}$ of anhydrous DMF. To this stirred solution was added $10 \mu \mathrm{L}$ of triethylamine. The reaction mixture was stirred at $25{ }^{\circ} \mathrm{C}$ and monitored by HPLC. Eight- $\mu \mathrm{L}$ aliquots were removed and diluted with $42 \mu \mathrm{L}$ of $1: 1 \mathrm{CH}_{3} \mathrm{CN}-50 \mathrm{mM} \mathrm{NH} 4 \mathrm{OAc}, \mathrm{pH} 4.5 ; 20 \mu \mathrm{L}$ of each diluted aliquot was analyzed on a $3 \mu \mathrm{m} \mathrm{C}_{18}$ reversed phase HPLC column $(250 \times 10$ $\mathrm{mm})$. The column was washed with $1 \% \rightarrow 63 \% \mathrm{CH}_{3} \mathrm{CN}-50 \mathrm{mM} \mathrm{NH}_{4} \mathrm{OAc}, \mathrm{pH} 4.5$, over a period of $45 \mathrm{~min}$ at a flow rate of $3.5 \mathrm{~mL} / \mathrm{min}$ (detection at $260 \mathrm{~nm}$; the desired product eluted at 13.4 min). After $20 \mathrm{~h}$, the remaining reaction mixture was diluted with $300 \mu \mathrm{L}$ of $1: 1 \mathrm{CH}_{3} \mathrm{CN}-50$ 
$\mathrm{mM} \mathrm{NH}_{4} \mathrm{OAc}, \mathrm{pH} 4.5$, and purified by $\mathrm{C}_{18}$ reversed phase HPLC on a semi-preparative column (250 x $10 \mathrm{~mm})$ using the same gradient as described above. $N$-(4-Pentenoyl)-(S)-citrulline pdCpA Ester (4-pdCpA) was recovered from the appropriate fractions as a colorless solid following lyophilization: yield $1 \mathrm{mg}(44 \%)$; mass spectrum (ESI), $\mathrm{m} / z \quad 876.1(\mathrm{M}+\mathrm{H})^{+}$; mass spectrum (FAB), $m / z \quad 876.2472\left(\mathrm{C}_{30} \mathrm{H}_{44} \mathrm{~N}_{11} \mathrm{O}_{16} \mathrm{P}_{2}\right.$ requires 876.2443).

1-[N-(4-Pentenoyl)]-4R-guanidinyl-S-proline pdCpA Ester (7-pdCpA).

I-[N-(4-Pentenoyl)]-4R-guanidinyl-S-proline. To a solution of $275 \mathrm{mg}(1.19 \mathrm{mmol})$ of 1-[tert.-butyloxycarbonyl]-4R-amino-S-proline (49) in $10 \mathrm{~mL}$ of methanol was added $445 \mathrm{mg}$ (3.58 mmol) of aminoiminomethanesulfonic acid (50). The reaction mixture was stirred at $25^{\circ} \mathrm{C}$ and a clear solution was formed after $3 \mathrm{~h}$. The reaction mixture was then stirred at $25{ }^{\circ} \mathrm{C}$ for another $16 \mathrm{~h}$. The solution was concentrated under diminished pressure and the residue was applied to a silica gel column $(20 \times 3 \mathrm{~cm})$. Elution with 2:1 and then 1:1 ethyl acetate-methanol, and finally with methanol, afforded Boc-protected ( $4 R$ )-guanidinyl- $S$-proline as a colorless powder. The structure of the intermediate was confirmed from its mass spectrum $(\mathrm{m} / \mathrm{z} 273.1$ $(\mathrm{M}+\mathrm{H})^{+}($theoretical 273.1)). This intermediate was treated with $4 \mathrm{~mL}$ of 3:1 dicholoromethanetrifluoroacetic acid and the reaction mixture was stirred at $25^{\circ} \mathrm{C}$ for $4 \mathrm{~h}$. The solution was concentrated under diminished pressure. The residue was co-evaporated three times with $5-\mathrm{mL}$ portions toluene to afford $N$-Boc- $4 R$-guanidinyl-S-proline as a syrup. The residue was dissolved in $10 \mathrm{~mL}$ of $1: 1$ water-dioxane and treated with $175 \mathrm{mg}(2.08 \mathrm{mmol})$ of $\mathrm{NaHCO}_{3}$. To this stirred solution was added $206 \mathrm{mg}$ (1.04 mmol) of the succinimidyl ester of pentenoic acid (46). The reaction mixture was stirred at $25{ }^{\circ} \mathrm{C}$ for $4 \mathrm{~h}$ and then acidified to $\mathrm{pH} 4$ by the addition of $1 \mathrm{~N}$ $\mathrm{NaHSO}_{4}$. The aqueous phase was extracted with $10 \mathrm{~mL}$ of ethyl acetate and the organic phase was discarded. The aqueous phase was concentrated under diminished pressure. The residue 
was suspended in $20 \mathrm{~mL}$ of methanol and the insoluble solid was filtered. The solid was washed two times with 10-mL portions of methanol. The combined methanol extract was concentrated under diminished pressure. The residue was purified by flash chromatography on a silica gel column $(18 \times 3 \mathrm{~cm})$. Elution with 1:1 ethyl acetate-methanol and then with methanol afforded 1-[N-(4-pentenoyl)]-4R-guanidinyl-S-proline as a colorless foam: overall yield $120 \mathrm{mg}$ (40\% for three steps); silica gel TLC $R_{f} 0.48$ (methanol); ${ }^{1} \mathrm{H}$ NMR $\left(\mathrm{CD}_{3} \mathrm{OD}\right) \delta 2.16-2.20(\mathrm{~m}, 1 \mathrm{H}), 2.25-$ $2.36(\mathrm{~m}, 4 \mathrm{H}), 3.37-2.40(\mathrm{~m}, 1 \mathrm{H}), 3.40-3.46(\mathrm{~m}, 1 \mathrm{H}), 3.76-3.91(\mathrm{~m}, 1 \mathrm{H}), 4.08-4.19(\mathrm{~m}, 1 \mathrm{H}), 4.27-$ $4.35(\mathrm{~m}, 1 \mathrm{H}), 4.97-5.04(\mathrm{~m}, 2 \mathrm{H})$ and 5.68-5.93 (m, 1H); mass spectrum $(\mathrm{ESI}), \mathrm{m} / \mathrm{z} 255.2$ $(\mathrm{M}+\mathrm{H})^{+} ;(\mathrm{FAB}), m / z, 255.1445\left(\mathrm{C}_{11} \mathrm{H}_{19} \mathrm{~N}_{4} \mathrm{O}_{3}\right.$ requires 255.1457). 1-[N-(4-Pentenoyl)]-4R-guanidinyl-S-proline Cyanomethyl Ester. 1-[N-(4-Pentenoyl)]$4 R$-guanidinyl- $S$-proline $(75 \mathrm{mg}, 0.275 \mathrm{mmol})$ was dissolved in $3 \mathrm{~mL}$ of anhydrous DMF and stirred at $25{ }^{\circ} \mathrm{C}$. To this stirred solution was added $142 \mu \mathrm{L}(0.82 \mathrm{mmol})$ of $N, N-$ diisopropylethylamine followed by $40 \mu \mathrm{L}(0.55 \mathrm{mmol})$ of $\mathrm{ICH}_{2} \mathrm{CN}$. The reaction mixture was stirred at $25{ }^{\circ} \mathrm{C}$ for $36 \mathrm{~h}$ and then concentrated under vacuum. $1-[N$-(4-Pentenoyl) $]-4 R$ guanidinyl-S-proline cyanomethyl ester was isolated as a crude product: yield $65 \mathrm{mg}(81 \%)$; mass spectrum (ESI), $m / z 294.3(\mathrm{M}+\mathrm{H})^{+}$(theoretical 294.1).

1-[N-(4-Pentenoyl)]-4R-guanidinyl-S-proline pdCpA Ester(7-pdCpA). A solution of the tris(tetrabutylammonium) salt of pdCpA (48) $(2.5 \mathrm{mg}, 1.84 \mu \mathrm{mol})$ dissolved in $50 \mu \mathrm{L}$ of anhydrous DMF was added to a dry conical vial containing $15 \mathrm{mg}$ (49 $\mu \mathrm{mol})$ of $1-[\mathrm{N}-(4-$ pentenoyl)]-4R-guanidinyl-S-proline cyanomethyl ester in $50 \mu \mathrm{L}$ of anhydrous DMF. To this stirred solution was added $10 \mu \mathrm{L}$ of triethylamine. The reaction mixture was stirred at $25^{\circ} \mathrm{C}$ and monitored by HPLC. Seven- $\mu \mathrm{L}$ aliquots were removed and diluted with $43 \mu \mathrm{L}$ of $1: 1 \mathrm{CH}_{3} \mathrm{CN}-$ $50 \mathrm{mM} \mathrm{NH} \mathrm{m}_{4} \mathrm{OAc}, \mathrm{pH} 4.5$; each diluted aliquot was analyzed on a $3 \mu \mathrm{m} \mathrm{C}_{18}$ reversed phase HPLC 
column $(250 \times 10 \mathrm{~mm})$. The column was washed with $1 \% \rightarrow 63 \% \mathrm{CH}_{3} \mathrm{CN}-50 \mathrm{mM} \mathrm{NH} \mathrm{OAc}_{4} \mathrm{pH}$ 4.5 , over a period of $45 \mathrm{~min}$ at a flow rate of $3.5 \mathrm{~mL} / \mathrm{min}$ (detection at $260 \mathrm{~nm}$; the desired 2'and 3'- $O$-acyl products eluted at $12.5 \mathrm{~min}$ and $12.9 \mathrm{~min}$ ). After $36 \mathrm{~h}$, the remaining reaction mixture was diluted with $300 \mu \mathrm{L}$ of $1: 1 \mathrm{CH}_{3} \mathrm{CN}-50 \mathrm{mM} \mathrm{NH} 4 \mathrm{OAc}, \mathrm{pH} 4.5$, and purified by $\mathrm{C}_{18}$ reversed phase HPLC on a semi preparative column $(250 \times 10 \mathrm{~mm})$ using the same gradient described above. 1-[N-(4-Pentenoyl)]-4R-guanidinyl- $S$-proline pdCpA ester (7-pdCpA) was recovered from the appropriate fractions as a colorless solid following lyophilization: yield 0.5 mg (31\%); mass spectrum (ESI), $m / z 873.3(\mathrm{M}+\mathrm{H})^{+}$; (theoretical 873.2).

\section{1-[N-(4-Pentenoyl)]-4S-guanidinylmethyl-S-proline pdCpA Ester (8-pdCpA).}

1-[N-(4-Pentenoyl)]-4S-guanidinylmethyl-S-proline. To a solution of $230 \mathrm{mg}(0.94$

mmol) of 1-[tert.-butyloxycarbonyl]-4S-aminomethyl-S-proline (49) in $15 \mathrm{~mL}$ of methanol was added $437 \mathrm{mg}$ (3.52 mmol) of aminoiminomethanesulfonic acid (50). The reaction mixture was stirred at $25{ }^{\circ} \mathrm{C}$ and a clear solution was formed after $2 \mathrm{~h}$. The reaction mixture was then stirred at $25{ }^{\circ} \mathrm{C}$ for another $16 \mathrm{~h}$. The solution was concentrated under diminished pressure and the residue was applied to a silica gel column $(32 \times 3.5 \mathrm{~cm})$. Elution with 1:1, 2:1, 4:1 and then 8:1 methanol-ethyl acetate, and finally with methanol, afforded Boc-protected $4 S$-guanidinylmethyl$S$-proline as a colorless powder: yield $75 \mathrm{mg}$; silica gel TLC $R_{f} 0.38$ (methanol); mass spectrum (ESI), $m / z 287.2(\mathrm{M}+\mathrm{H})^{+}$(theoretical 287.3). Boc-protected $4 S$-guanidinylmethyl-S-proline was treated with $4 \mathrm{~mL}$ of 3:1 dicholoromethane-trifluoroacetic acid and the reaction mixture was stirred at $25{ }^{\circ} \mathrm{C}$ for $4 \mathrm{~h}$. The solution was concentrated under diminished pressure. The residue was co-evaporated three times with 5 -mL portions of toluene to afford $4 S$-guanidinylmethyl-Sproline as a syrup. The residue was dissolved in $6 \mathrm{~mL}$ of $1: 1$ water-dioxane and treated with 44 $\mathrm{mg}(0.52 \mathrm{mmol})$ of $\mathrm{NaHCO}_{3}$. To this stirred solution was added $62 \mathrm{mg}(0.31 \mathrm{mmol})$ of 
succinimidyl pentenoate (46). The reaction mixture was stirred at $25^{\circ} \mathrm{C}$ for $4 \mathrm{~h}$ and then acidified to $\mathrm{pH} 4$ by addition of $1 \mathrm{~N} \mathrm{NaHSO}_{4}$. The aqueous layer was extracted with $10 \mathrm{~mL}$ of ethyl acetate and the organic phase was discarded. The aqueous phase was concentrated under diminished pressure. The residue was suspended in $15 \mathrm{~mL}$ of methanol and the insoluble solid was filtered. The solid was washed two times with $10-\mathrm{mL}$ portions of methanol. The combined methanol extract was concentrated under diminished pressure. The residue was purified by flash chromatography on a silica gel column $(30 \times 2 \mathrm{~cm})$. Elution with 1:1 and then 2:1 methanolethyl acetate, and finally with methanol, afforded 1-[N-(4-pentenoyl)]-4S-guanidinylmethyl-Sproline as a colorless powder: overall yield $60 \mathrm{mg}$ ( $24 \%$ for three steps); silica gel TLC $R_{f} 0.30$ (methanol); ${ }^{1} \mathrm{H}$ NMR $\left(\mathrm{CD}_{3} \mathrm{OD}\right) \delta$ 2.27-2.45 (m, 5H), 2.55 (s, $\left.2 \mathrm{H}\right), 3.09-3.28(\mathrm{~m}, 3 \mathrm{H}), 3.65-3.87$ $(\mathrm{m}, 1 \mathrm{H}), 4.11-4.32(\mathrm{~m}, 1 \mathrm{H}), 4.88-5.06(\mathrm{~m}, 2 \mathrm{H})$ and 5.65-5.95 $(\mathrm{m}, 1 \mathrm{H})$; mass spectrum $(\mathrm{ESI}), \mathrm{m} / \mathrm{z}$ $269.3(\mathrm{M}+\mathrm{H})^{+}$; mass spectrum (FAB), $m / z, 269.1608\left(\mathrm{C}_{12} \mathrm{H}_{21} \mathrm{~N}_{4} \mathrm{O}_{3}\right.$ requires 269.1614). 1-[N-(4-Pentenoyl)]-4S-guanidinylmethyl-S-proline Cyanomethyl Ester. 1-[N-(4Pentenoyl)]-4S-guanidinylmethyl-S-proline (50 mg, $0.186 \mathrm{mmol}$ ) was dissolved in $3 \mathrm{~mL}$ of anhydrous DMF and stirred at $25{ }^{\circ} \mathrm{C}$. To this stirred solution was added $127 \mu \mathrm{L}(0.74 \mathrm{mmol})$ of $N, N$-diisopropylethylamine followed by $27 \mu \mathrm{L}(0.37 \mathrm{mmol})$ of $\mathrm{ICH}_{2} \mathrm{CN}$. The reaction mixture was stirred at $25^{\circ} \mathrm{C}$ for $18 \mathrm{~h}$ and then concentrated under diminished pressure. 1-[N-(4Pentenoyl)]-4S-guanidinylmethyl-S-proline cyanomethyl ester was isolated as a crude product: yield $60 \mathrm{mg}$; mass spectrum (ESI), $\mathrm{m} / \mathrm{z} 308.3(\mathrm{M}+\mathrm{H})^{+}$(theoretical 308.2).

1-[N-(4-Pentenoyl)]-4S-guanidinylmethyl-S-proline pdCpA Ester (8-pdCpA). A solution of the tris(tetrabutylammonium) salt of pdCpA (48) $(2.5 \mathrm{mg}, 1.84 \mu \mathrm{mol})$ dissolved in $50 \mu \mathrm{L}$ of anhydrous DMF was added to a dry conical vial containing $15 \mathrm{mg}(49 \mu \mathrm{mol})$ of 1-[N-(4pentenoyl)]-4S-guanidinylmethyl-S-proline cyanomethyl ester in $50 \mu \mathrm{L}$ of anhydrous DMF. To 
this stirred solution was added $10 \mu \mathrm{L}$ of triethylamine. The reaction mixture was stirred at $25^{\circ} \mathrm{C}$ and monitored by HPLC. Seven- $\mu \mathrm{L}$ aliquots were removed and diluted with $43 \mu \mathrm{L}$ of 1:1 $\mathrm{CH}_{3} \mathrm{CN}-50 \mathrm{mM} \mathrm{NH} \mathrm{N}_{4} \mathrm{OAc}, \mathrm{pH} 4.5$; each diluted aliquot was analyzed on a $3 \mu \mathrm{m} \mathrm{C}_{18}$ reversed phase HPLC column $(250 \times 10 \mathrm{~mm})$. The column was washed with $1 \% \rightarrow 63 \% \mathrm{CH}_{3} \mathrm{CN}-50 \mathrm{mM}$ $\mathrm{NH}_{4} \mathrm{OAc}, \mathrm{pH} 4.5$, over a period of $45 \mathrm{~min}$ at a flow rate of $3.5 \mathrm{~mL} / \mathrm{min}$ (detection at $260 \mathrm{~nm}$; the desired 2'- and 3'-O-acyl products had retention times at $13.7 \mathrm{~min}$ and $14.0 \mathrm{~min})$. After $36 \mathrm{~h}$, the remaining reaction mixture was diluted with $300 \mu \mathrm{L}$ of $1: 1 \mathrm{CH}_{3} \mathrm{CN}-50 \mathrm{mM} \mathrm{NH} \mathrm{H}_{4} \mathrm{OAc}, \mathrm{pH} 4.5$, and purified by $\mathrm{C}_{18}$ reversed phase HPLC on a semi-preparative column ( $\left.250 \times 10 \mathrm{~mm}\right)$ using the same gradient described above. 1-[N-(4-Pentenoyl)]-4S-guanidinomethyl-S-proline pdCpA ester $(\mathbf{8}$-pdCpA) was recovered from the appropriate fractions as a colorless solid following lyophilization: yield $0.4 \mathrm{mg}(25 \%)$; mass spectrum (ESI), $\mathrm{m} / \mathrm{z} 887.3(\mathrm{M}+\mathrm{H})^{+}$; mass spectrum (FAB), $m / z 887.2597\left(\mathrm{C}_{31} \mathrm{H}_{45} \mathrm{~N}_{12} \mathrm{O}_{15} \mathrm{P}_{2}\right.$ requires 887.2603). N-(4-Pentenoyl)-S-proline pdCpA Ester (9-pdCpA). N-(4-Pentenoyl)-S-proline. Proline (230 mg, $2 \mathrm{mmol})$ was dissolved in $10 \mathrm{~mL}$ of 1:1 water-dioxane and treated with $252 \mathrm{mg}(3.0 \mathrm{mmol})$ of $\mathrm{NaHCO}_{3}$. To this stirred solution was added $395 \mathrm{mg}$ ( $2.0 \mathrm{mmol})$ of the succinimidyl ester of pentenoic acid (46). The reaction mixture was stirred at $25{ }^{\circ} \mathrm{C}$ for $4 \mathrm{~h}$ and then acidified to $\mathrm{pH} 4$ by the addition of $1 \mathrm{~N} \mathrm{NaHSO}_{4}$. The aqueous phase was extracted twice with 15 -mL portions of ethyl acetate. The organic layer was washed with $5 \mathrm{~mL}$ of brine, dried $\left(\mathrm{Na}_{2} \mathrm{SO}_{4}\right)$, filtered and then concentrated under diminished pressure. The residue was suspended in $20 \mathrm{~mL}$ of methanol and the insoluble solid was filtered. The solid was washed twice with $10-\mathrm{mL}$ portions of methanol. The combined methanol extract was concentrated under diminished pressure. The residue was purified by flash chromatography on a silica gel column $(18 \times 3 \mathrm{~cm})$. Elution with ethyl acetate, followed by 4:1, 2:1 and then 1:1 
ethyl acetate-methanol afforded $N$-(4-pentenoyl)-S-proline as a syrup: yield $200 \mathrm{mg}(51 \%)$;

silica gel TLC $R_{f} 0.2$ (4:1 ethyl acetate-methanol); ${ }^{1} \mathrm{H}$ NMR $\left(\mathrm{CDCl}_{3}\right) \delta 1.79-1.94(\mathrm{~m}, 1 \mathrm{H}), 1.96-$ $2.08(\mathrm{~m}, 1 \mathrm{H}), 2.09-2.20(\mathrm{~m}, 1 \mathrm{H}), 2.22-2.47(\mathrm{~m}, 4 \mathrm{H}), 2.55-2.67(\mathrm{~m}, 1 \mathrm{H}), 3.29-3.67(\mathrm{~m}, 2 \mathrm{H}), 4.20-$

$4.46(\mathrm{~m}, 1 \mathrm{H}), 4.85-5.11(\mathrm{~m}, 2 \mathrm{H})$ and 5.75-5.92 (m, 1H); mass spectrum (ESI), $\mathrm{m} / z 198.2$

$(\mathrm{M}+\mathrm{H})^{+}$; mass spectrum $(\mathrm{FAB}), \mathrm{m} / z 198.1134\left(\mathrm{C}_{10} \mathrm{H}_{16} \mathrm{NO}_{3}\right.$ requires 198.1131).

N-(4-Pentenoyl)-S-proline Cyanomethyl Ester. To a stirred solution of $150 \mathrm{mg}(0.76$

mmol) of $N$-(4-pentenoyl)-S-proline in $5 \mathrm{~mL}$ of $\mathrm{CH}_{3} \mathrm{CN}$ was added $390 \mu \mathrm{L}$ (2.28 mmol) of $\mathrm{N}, \mathrm{N}$ diisopropylethylamine followed by $110 \mu \mathrm{L}(1.52 \mathrm{mmol})$ of $\mathrm{ICH}_{2} \mathrm{CN}$. The reaction mixture was stirred at $25{ }^{\circ} \mathrm{C}$ for $12 \mathrm{~h}$ and then diluted with $20 \mathrm{~mL}$ of ethyl acetate. The organic layer was washed successively with 5 -mL portions of $1 \mathrm{~N} \mathrm{HCl}$ solution, saturated $\mathrm{NaHCO}_{3}$ solution and brine. The organic phase was dried $\left(\mathrm{Na}_{2} \mathrm{SO}_{4}\right)$, filtered and then concentrated under diminished pressure. The residue was purified by flash chromatography on a silica gel column $(25 \times 2 \mathrm{~cm})$. Elution with 4:1, 2:1 and then 1:1 hexane-ethyl acetate afforded the $N$-(4-pentenoyl)-S-proline cyanomethyl ester as a semisolid: yield $140 \mathrm{mg}$ (78\%); silica gel TLC $R_{f} 0.55$ (1:1 hexane-ethyl acetate); ${ }^{1} \mathrm{H} \mathrm{NMR}\left(\mathrm{CDCl}_{3}\right) \delta$ 1.75-2.43 (m, 8H), 3.36-3.60 (m, 2H), 4.28-4.44 (m, 1H), 4.56-5.02 (m, 4H) and 5.66-5.85 $(\mathrm{m}, 1 \mathrm{H})$; mass spectrum $(\mathrm{ESI}), \mathrm{m} / z 237.3(\mathrm{M}+\mathrm{H})^{+}$; mass spectrum (FAB), $m / z 237.1237\left(\mathrm{C}_{12} \mathrm{H}_{17} \mathrm{~N}_{2} \mathrm{O}_{3}\right.$ requires 237.1240).

N-(4-Pentenoyl)-S-proline pdCpA Ester (9-pdCpA). A solution of the tris(tetrabutylammonium) salt of pdCpA (48) $(2.5 \mathrm{mg}, 1.84 \mu \mathrm{mol})$ dissolved in $50 \mu \mathrm{L}$ of anhydrous DMF was added to a dry conical vial containing $15 \mathrm{mg}(63 \mu \mathrm{mol})$ of $N$-(4-pentenoyl)$S$-proline cyanomethyl ester in $50 \mu \mathrm{L}$ of anhydrous DMF. To this stirred solution was added 10 $\mu \mathrm{L}$ of triethylamine. The reaction mixture was stirred at $25{ }^{\circ} \mathrm{C}$ and monitored by HPLC. Seven$\mu \mathrm{L}$ aliquots were removed and diluted with $43 \mu \mathrm{L}$ of $1: 1 \mathrm{CH}_{3} \mathrm{CN}-50 \mathrm{mM} \mathrm{NH}_{4} \mathrm{OAc}, \mathrm{pH} 4.5$; the 
diluted aliquot was analyzed on a $3 \mu \mathrm{m} \mathrm{C}_{18}$ reversed phase HPLC column $(250 \times 10 \mathrm{~mm})$. The column was washed with $1 \% \rightarrow 63 \% \mathrm{CH}_{3} \mathrm{CN}-50 \mathrm{mM} \mathrm{NH} 4 \mathrm{OAc}, \mathrm{pH} 4.5$, over a period of 45 min at a flow rate of $3.5 \mathrm{~mL} / \mathrm{min}$ (detection at $260 \mathrm{~nm}$; the desired product eluted at $16.3 \mathrm{~min}$ ). After $18 \mathrm{~h}$, the remaining reaction mixture was diluted with $300 \mu \mathrm{L}$ of $1: 1 \mathrm{CH}_{3} \mathrm{CN}-50 \mathrm{mM} \mathrm{NH}_{4} \mathrm{OAc}$, $\mathrm{pH} 4.5$, and purified by $\mathrm{C}_{18}$ reversed phase HPLC on a semi-preparative column $(250 \times 10 \mathrm{~mm})$ using the same gradient as described above. $N$-(4-Pentenoyl)- $S$-proline pdCpA ester (9-pdCpA). was recovered from the appropriate fractions as a colorless solid following lyophilization: yield

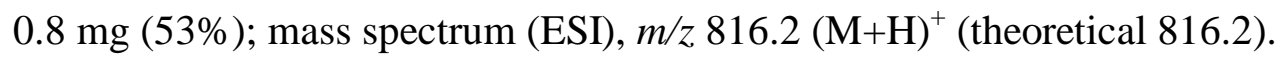


Scheme 1<smiles>C=CCCC(=O)NC(CCCNC(=N)NCCCC(N)C(=O)O)C(=O)ON1C(=O)CCC1=O</smiles>

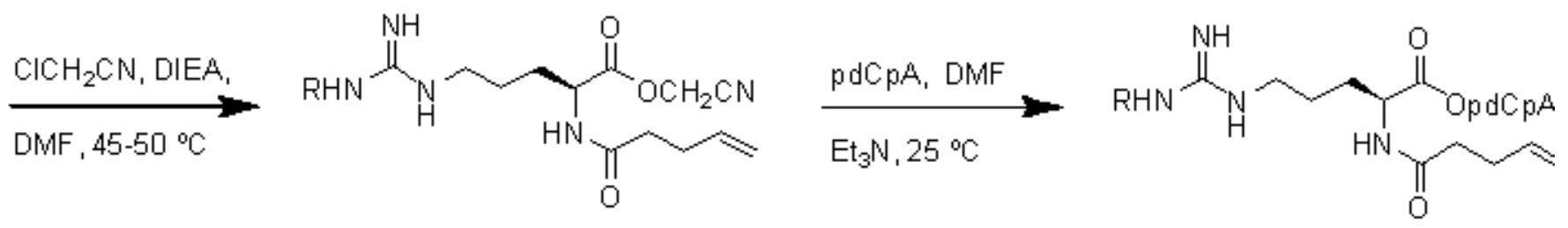

1-pdCpA R $=\mathrm{H}$

2-pdCpA R $=\mathrm{CH}_{3}$

3-pdCpA R $=\mathrm{NO}_{2}$ 
Scheme 2

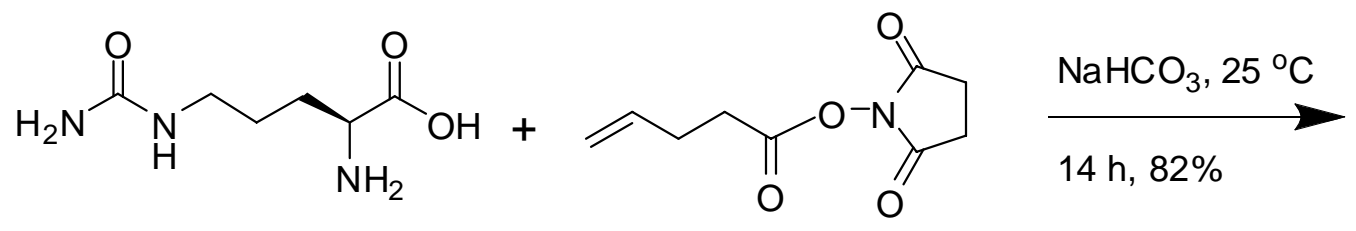<smiles>C=CCCC(=O)N[C@@H](CCCOC(=O)[C@H](CCCNC(N)=O)NC(=O)CCC=C)C(=O)O</smiles>

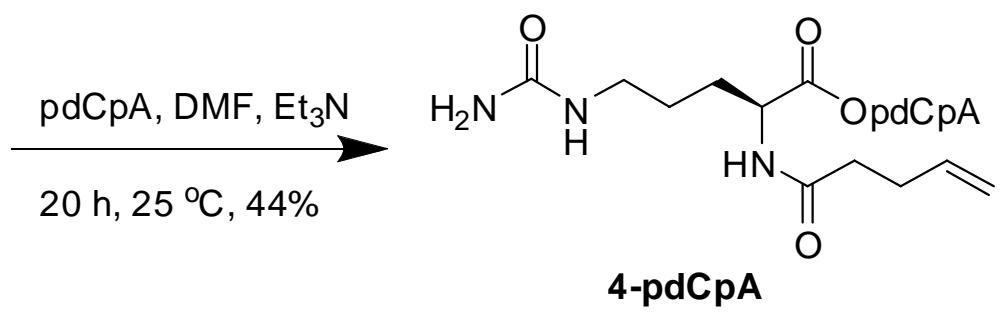


Scheme 3<smiles>CC(C)(C)OC(=O)N1C[C@@H](N)C[C@H]1C(=O)[OH2+]</smiles><smiles>[R5][R5]([H])([H])C1CC1</smiles><smiles>CC(C)(C)OC(=O)N1C[C@H](NC(=N)N)CC1C(=O)O</smiles><smiles>N=C(N)NC1CNC(C(=O)O)C1</smiles><smiles>C=CCCC(=O)ON1C(=O)CCC1=O</smiles>

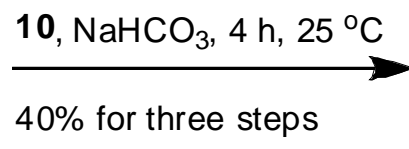

pdCpA, DMF, $\mathrm{Et}_{3} \mathrm{~N}$

$\mathrm{ICH}_{2} \mathrm{CN}$, DIEA

DMF, $36 \mathrm{~h}, 25^{\circ} \mathrm{C}$<smiles>C=CCCC(=O)N1C[C@H](C)C[C@H]1C(=O)OCC=N</smiles><smiles>C=CCCC(=O)N1C[C@@H](NC(=N)N)C[C@H]1C(=O)OC(=O)OCc1ccccc1</smiles>

7-pdCpA 
Scheme 4

<smiles>C=CCCC(=O)ON1C(=O)CCC1=O</smiles>

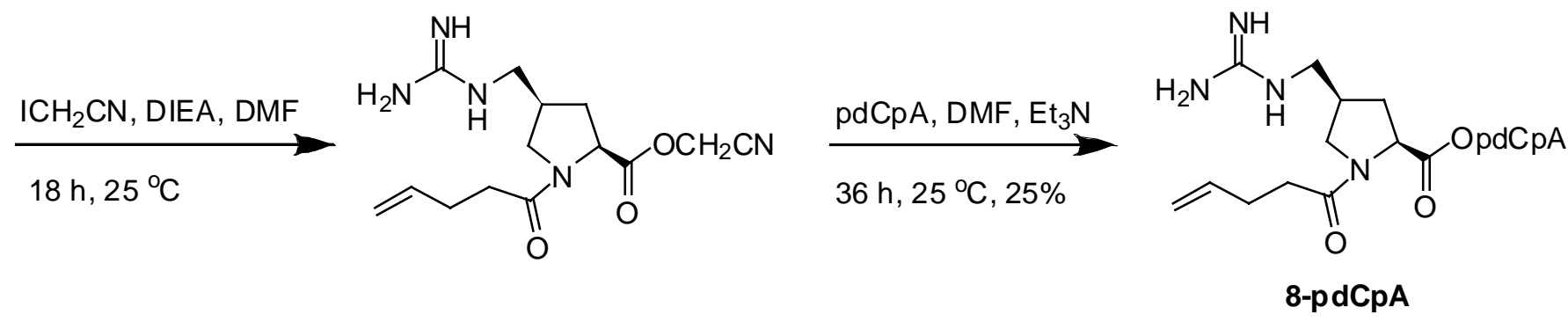


Scheme 5
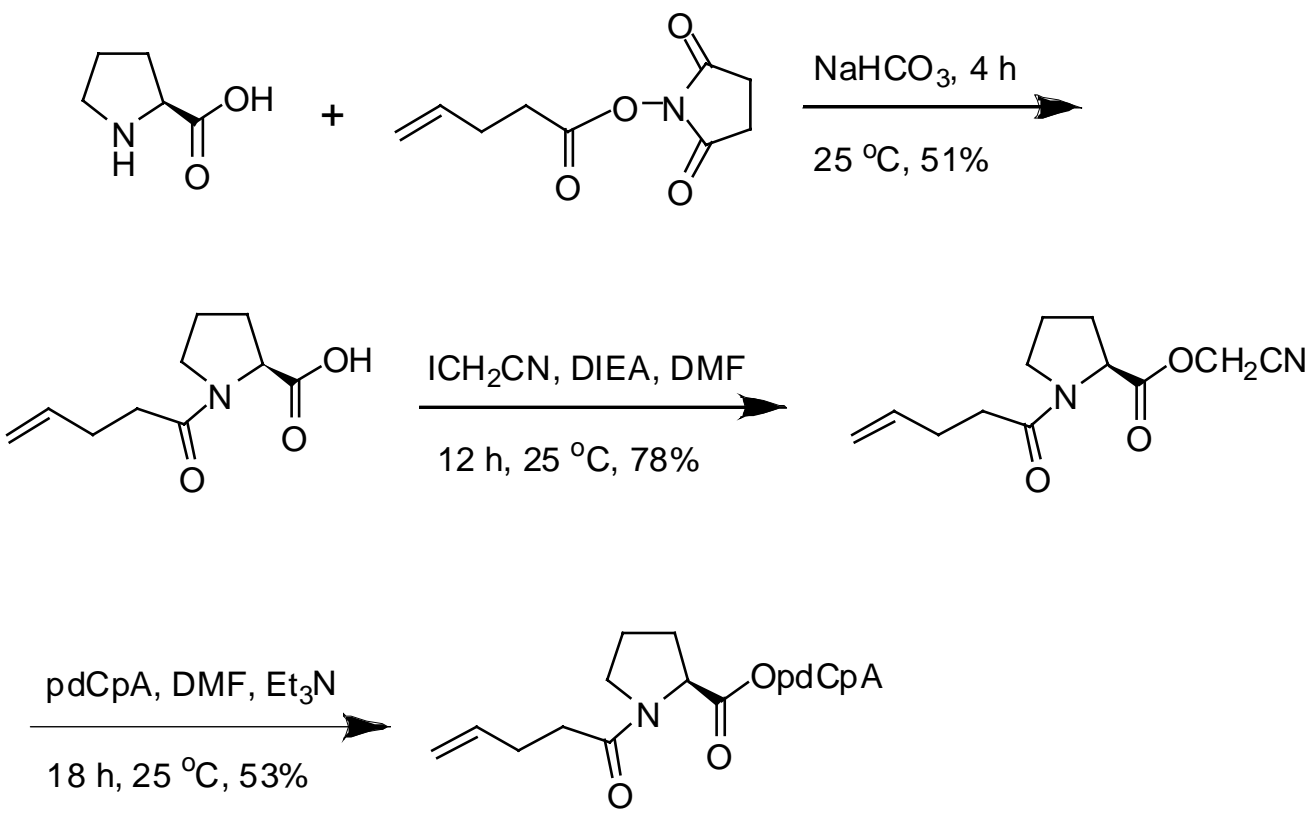

9-pdCpA 